\title{
Production and Bromatological Composition of Black Oat Cultivated with Vetch When Submitted to Nitrogen Fertilization in Above Sowing in the Pasture of Tifton 85
}

\author{
João Paulo Fonesi de Carvalho ${ }^{1}$, Magno Daniel Porfirio ${ }^{1}$, Claudia Anete Führ ${ }^{1}$, Vitor Gustavo Kuhn ${ }^{2}$, \\ Tauane Santos Brito ${ }^{2}$, Renan $\mathrm{Pan}^{2}$, Nelson Massaru Fukumoto ${ }^{3} \&$ Eduardo Eustáquio Mesquita ${ }^{4}$ \\ ${ }^{1}$ Postgraduate Program in Zootechnics, State University of the West of Paraná, Marechal Cândido Rondon, PR, \\ Brazil \\ ${ }^{2}$ Postgraduate Program in Agronomy, State University of the West of Paraná, Marechal Cândido Rondon, PR, \\ Brazil \\ ${ }^{3}$ Teacher of the Course of Agronomy in the Institution, Pontifical Catholic University of Parana, Toledo, PR, \\ Brazil \\ ${ }^{4}$ Teacher of the Course of Agronomy in the Institution, State University of the West of Paraná, Marechal Cândido \\ Rondon, PR, Brazil \\ Correspondence: João Paulo Fonesi de Carvalho, Postgraduate Program in Zootechnics, State University of the \\ West of Paraná, Marechal Cândido Rondon, PR, Brazil. Tel: 55-44-99808-4103. E-mail: \\ joao.fonesi@hotmail.com
}

Received: November 8, 2017

Accepted: December 11, 2017 Online Published: January 15, 2018

doi:10.5539/jas.v10n2p328

URL: https://doi.org/10.5539/jas.v10n2p328

\begin{abstract}
The objective of this research was to evaluate the forage production, the bromatological composition of black oat in consortium with vetch when submitted to nitrogen fertilization in above sowing system in the Tifton 85 pasture. The experiment was conducted at the experimental farm of the Pontifical Catholic University of Parana, Campus Toledo-PR. The experimental design used was random blocks with four treatments and five repetitions and the treatments consisted of: only oat, oat consorted with vetch, oat with nitrogen fertilization and oat consorted with vetch and nitrogen fertilization. Were evaluated the bromatological composition (CP, NDF, ADF, LIG, EE DM, MM) and the forage yield in the consortium of oat with vetch and/or nitrogen fertilization. The results obtained to the bromatological composition indicate that the application of nitrogen on the surface of the forage increased production with an average of $3.922 \mathrm{~kg} \mathrm{ha}^{-1}$ in the second year. The nitrogen fertilization also influenced in the medium contents of crude protein (CP) with $18.56 \%$ in the first year. The increase of nitrogen in the parcels showed meaningful results for the first year $(\mathrm{P}<0.05)$ in the contents of dry matter with average value of $18.95 \%$. The introduction of black oat consorted with vetch and with a nitrogen fertilization in above sowing in the crop of tifton 85 during the winter period provides an increase in the yield $\mathrm{kg} \mathrm{ha}^{-1}$ and when the vetch was used it happened an increase in the contents of crude protein and dry matter in the bromatological composition of the forage.
\end{abstract}

Keywords: dry matter, crude protein, nitrogen

\section{Introduction}

The pasture production systems suffer with the decrease on the development and growth of forage affecting directly the animal development during the winter and autumn. The yield decline is attributed to the seasonality of the fodder species where most of the plants are adapted to the tropical climate and have significant development during the spring and summer (Piazzetta, 2007).

The forage Tifton 85 (Cynodon dactylon) is highlighted by its high productive potential resistance to animal trampling and also allows the organic matter recycling on the soil. During the winter and autumn shows a production seasonality due to the decline on the temperature and occurrences of frost. The above sowing of forage is an alternative to extend the period of forage use, increasing the contribution of biomass to feed the animals (Londero et al., 2013). 
The black oat (Avena strigosa) is the main winter forage used in above sowing due to its high forage potential, high dry matter production, nutritional quality, rusticity, tolerance to soil acidity allied to a low production cost. The black oat belongs to the Poaceae family mostly used as an above sowing crop on south of Brazil due to the climatic conditions, of the annual crop have adaptability to temperate and subtropical climates (Londero et al., 2013).

The above sowing is a technique that allows the establishment of annual crops on already developed pasture by adding perennial species without destroying the pre-established crop. With this practice, it is possible to contribute on the reduction of the competition per area in rural production units with development of dairy and meat activities generating an increase in forage production and consequently a better utilization of this area (Bergoli et al., 2011).

The common vetch (Vicia sativa L.) is a legume form the Fabaceae family, annual for winter, used on south of Brazil, with a fundamental importance because of its capacity of nitrogen incorporation and improvement on the fertility and quality of pasture (Renato et al., 2012).

The consortium of leguminous species with winter annual grasses is one of the alternatives to minimize nitrogen fertilization costs due to the high cost of nitrogen (Deminicis, 2009). With the use of consortium, the availability of this nutrient for the plants is improved consequently promotes an increase in the nutritional value from the pasture which will be ingested by the animals (Carvalho \& Pires, 2008). This contribution is possible linked to the ability of the legumes to fix nitrogen, improving the availability of this nutrient for the plants grown in a consortium and extending the productive capacity of the soil (Cantarutti et al., 2002).

The objective of this research was to evaluate the forage production, the bromatological composition of black oat in consortium with vetch when submitted to nitrogen fertilization in above sowing system in the Tifton 85 pasture.

\section{Material and Methods}

The experiment was conducted at the experimental farm of the Pontifical Catholic University of Parana, Campus

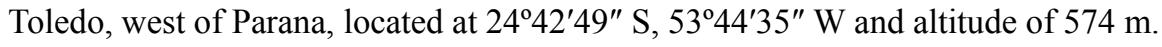

The West region of Parana, according to the climatic classification-According to Koppen is influenced by the Cfa climate-subtropical zone with hot summers, without dry seasons and a small frequency of frosts (IAPAR, 2013).

About the soil type of the experimental farm it is classified as Eutrophic Red Latosol (EMBRAPA, 2006), with the following chemical characteristics obtained from soil analysis performed in the layer of $0-20 \mathrm{~cm}: \mathrm{Al}$ exchangeable $0.10 \mathrm{cmolc} \mathrm{dm}^{-3}$; Ca exchangeable $5.97 \mathrm{cmolc} \mathrm{dm}^{-3} ; \mathrm{Mg}$ exchangeable $2.38 \mathrm{cmolc} \mathrm{dm}^{-3} ; \mathrm{P}$ available $9 \mathrm{cmolc} \mathrm{dm}^{-3}$ and $\mathrm{K}$ exchangeable $0.19 \mathrm{cmolc} \mathrm{dm}^{-3}$.

The experimental design used was random blocks, with parcels of 6 meters of length by 2.89 meters wide totalizing $17.34 \mathrm{~m}^{2}(2.89 \times 6.00 \mathrm{~m})$ per parcel, each one was compound of 17 lines with spacing of $0.17 \mathrm{~m}$. The spacing for line seeding of grain production, forage, green manure and as a cover for the soil must be of 17 to 20 $\mathrm{cm}$ and the seeding depth must vary from 2 to $4 \mathrm{~cm}$ (Primavesi et al., 2000). The experiment was composed 4 treatments (Oat, Oat with nitrogen fertilizer, Oat in consortium with vetch, Oat in consortium with vetch and with nitrogen fertilizer) with five repetitions totalizing 20 parcels.

The crops of black oat and vetch were seeded for two years, in the first year the above sowing was done on April 17, 2014. On the second year the above seeding of the species was performed on May 2, 2015 mechanically by means of a seeder with a density of $100 \mathrm{~kg}$ ha- 1 of seeds for all the treatments (independently of the mixture) and quantity that is adjusted according to the forage productivity expectancy. On the seeding date was applied on the seeding line $200 \mathrm{~kg} \mathrm{ha}^{-1}$ of fertilizer with formula of 10-20-20 (Primavesi et al., 2000).

To the treatments that received nitrogen fertilization, was applied in coverage ammonium sulfate in the doses of $80 \mathrm{~kg} \mathrm{ha}^{-1}$ of nitrogen parceled in three being the first application performed forty five days after seeding, the second and third applications were distributed posteriorly at the first and second cut of the forage. The method used to applicate the fertilizer was manually (Primavesi et al., 2000).

The collections were carried out in three samplings on the days 02/06/2014 about 45 days after seeding being followed by the second and third cut with an interval of approximately 30 days, on the days $02 / 07 / 2014$ and $02 / 08 / 2014$. In the second year the samples were also done on three stages at 16/06/2015, 17/07/2015 and $16 / 08 / 2015$ respectively. 
The samples (black oat and/or vetch and tifton) were collected by means of a metal square with known area $\left(0.25 \mathrm{~m}^{2}\right)$ hurled randomly twice each parcel and all the plants in its interior were cut $5 \mathrm{~cm}$ from the soil. After this procedure was performed the identification and weighing from each parcel, the obtained data was used to estimate the green matter production in $\mathrm{kg} \mathrm{ha}^{-1}$. Then removed $150 \mathrm{~g}$ of samples from each plot and were sent to a forced ventilation oven at $55^{\circ} \mathrm{C}$ for 72 hours to determine Dry Matter (Silva \& Queiroz, 2002). The material removed from the stove were milled using a Willey type mill, equipped with a $1 \mathrm{~mm}$ screen, and further this ground material was stored in plastic pots identified for the later bromatological analyses.

For the samples were determined the bromatological composition of the dry matter content (DM), crude protein (CP), ethereal extract (EE) and ashes, according to the methodology described by AOAC (1990) and neutral detergent fiber (NDF), acid detergent fiber (ADF) and lignin according to the methodology described by Van Soest et al. (1991).

The data obtained were presented as an average of three samples in relation to the effect of oat consortium with winter forages, bromatological composition. Analysis was performed by ANOVA using the statistical software SISVAR 5.3 (Ferreira, 2008). The differences were calculated by Tukeyand $\mathrm{p}<0.05$ was considered significant.

\section{Results and Discussion}

At table 1 are presented the averages of the three evaluations of the forages in the year of 2014. The results did not differ $(p>0.05)$ to the ethereal extract, mineral matter, neutral detergent fiber, acid detergent acid and lignin. In relation to the dry matter content it is possible to observe that the treatments consortium + nitrogen fertilization obtained the highest averages of dry matter percentage $21.29 \%$, compared to the oat and not fertilized treatments $17.53 \%$.

The results obtained (Table 1) were higher in the oat intercropping with vetch, with addition of nitrogen fertilizer, with $21.29 \%$ dry matter. However, the treatment yielded an average of $18.59 \%$ (DM), a superior result when compared to the one found fro Lana (2007) which was $14 \%$ of DM.

Table 1. Oat chemical evaluation of the four performed treatments: only oats, oat consorted with vetch, oat consorted with vetch and with nitrogen fertilization, only oat with nitrogen fertilizer in the year 2014

\begin{tabular}{lllllll}
\hline Elements & Oat & Oat + N & Oat+ Vetch & Oat+ Vetch + N & General Average & CV \\
\hline DM (\%) & $17.53 \mathrm{c}$ & $19.30 \mathrm{~b}$ & $17.66 \mathrm{bc}$ & $21.29 \mathrm{a}$ & 18.95 & 4.66 \\
CP (\%) & $16.06 \mathrm{~b}$ & $21.07 \mathrm{a}$ & $16.74 \mathrm{~b}$ & $20.36 \mathrm{a}$ & 18.56 & 5.44 \\
EE (\%) & $2.28 \mathrm{a}$ & $2.06 \mathrm{a}$ & $2.21 \mathrm{a}$ & $2.54 \mathrm{a}$ & 2.27 & 16.15 \\
MM (\%) & $9.16 \mathrm{a}$ & $8.16 \mathrm{a}$ & $9.24 \mathrm{a}$ & $8.13 \mathrm{a}$ & 8.67 & 15.75 \\
NDF (\%) & $53.41 \mathrm{a}$ & $51 \mathrm{a}$ & $52.05 \mathrm{a}$ & $52.93 \mathrm{a}$ & 52.35 & 4.9 \\
ADF (\%) & $25.63 \mathrm{a}$ & $26.53 \mathrm{a}$ & $25.92 \mathrm{a}$ & $27.54 \mathrm{a}$ & 26.41 & 7.02 \\
LIG (\%) & $6.66 \mathrm{a}$ & $8.11 \mathrm{a}$ & $6.98 \mathrm{a}$ & $6.94 \mathrm{a}$ & 7.17 & 29.48 \\
\hline
\end{tabular}

Note. Treatments: 1 (Oat), 2 (Oat + nitrogen fertilization), 3 (Oat + Vetch), and 4 (Oat + vetch + nitrogen fertilization); DM (Dry matter); CP (Crude Protein); EE (Etheral extract); MM (Mineral Matter); NDF (Neutral Detergent Fiber); ADF (Acid Detergent Fiber); LIG (Lignin); CV (Coeffeicient of Variation).

Averages in the same line followed by the same letter do not differ from one another $(\mathrm{P}>0.05)$ by the Tukey test.

Source: The author, 2014.

In relation to the values of crude protein it is possible to notice that it did have significant difference $(\mathrm{P}>0.05)$ among treatments, stating higher percentage in the second and fourth treatments with $21.07 \%$ and $20.36 \%$ respectively. To the crude protein analysis it was verified in the first year, according to the average of the evaluation of the three forages, that the highest percentage occurred when the black oat was consorted with vetch + nitrogen fertilization $(20.36 \% \mathrm{CP})$ which, when compared to those obtained by Vilela (2005), obtained higher mean values with $(26.1 \% \mathrm{CP})$ while in the second year the percentage was of $15.36 \%(\mathrm{CP})$ in the same treatment.

To the percentage of mineral matter (MM), it is possible to verify more stable values keeping an average of $8.67 \%$ among the treatments, not occurring significant variation $(\mathrm{P}>0.05)$. The content of ethereal extract determined in each treatment did not differ among the cultivars $(\mathrm{P}>0.05)$. 
The obtained results for neutral detergent fiber (NDF) in Table 1 did not differ $(\mathrm{P}>0.05)$ among treatments varying from $51 \%$ to $5341 \%$ of NDF. The acid detergent fiber (ADF) also not differed ( $P>0.05)$, maintaining an average of $26.41 \%$ (ADF), the lignin had not showed any significant variation $(\mathrm{P}>0.05)$ with a general average of $7.17 \%$ independently of the treatment. The values for NDF showed a higher percentage to oat (first treatment) and oat consorted with vetch and nitrogen fertilization (fourth treatment) according to Table 1 with average values of 53.41 and $52.93 \%$ respectively making it possible for the current average level of NDF be able to be used to feed ruminants (55-60\% of NDF) found by Van Soest (1994).

About the values for acid detergent fiber it is verified an oscillation between the years that the experiment was performed, having the highest levels during the second year when it reached the average of $36.77 \%$ and when compared to the first year the average was $26.41 \%$.

At the Table 2 are showed the averages of the three forage evaluations executed in the second year it is verified that the evaluated average contents did not differ significantly $(\mathrm{P}>0.05)$ independently of the treatment that was used. However, it determined a higher quantity of dry matter in the second year in the fourth treatment with $24.55 \%$ when compared to the values found in the first year also in the fourth treatment with average of $21.29 \%$ of dry matter showing a slight decrease as shown in Table 1 for each treatment.

Table 2. Oat chemical evaluation of the four performed treatments: only oats, oat consorted with vetch, oat consorted with vetch and with nitrogen fertilization, only oat with nitrogen fertilizer in the year 2015

\begin{tabular}{lllllll}
\hline Elements & Oat & Oat + N & Oat+ Vetch & Oat+ Vetch + N & General Average & CV \\
\hline DM (\%) & $23.46 \mathrm{a}$ & $25.15 \mathrm{a}$ & $22.80 \mathrm{a}$ & $24.55 \mathrm{a}$ & 23.99 & 6.33 \\
CP (\%) & $14.20 \mathrm{a}$ & $15.39 \mathrm{a}$ & $15.42 \mathrm{a}$ & $15.63 \mathrm{a}$ & 15.16 & 8.13 \\
EE (\%) & $3.35 \mathrm{a}$ & $3.08 \mathrm{a}$ & $2.94 \mathrm{a}$ & $3.03 \mathrm{a}$ & 3.1 & 21.19 \\
MM (\%) & $9.45 \mathrm{a}$ & $9.27 \mathrm{a}$ & $8.89 \mathrm{a}$ & $9.35 \mathrm{a}$ & 9.24 & 4.7 \\
NDF (\%) & $68.92 \mathrm{a}$ & $68.20 \mathrm{a}$ & $69.48 \mathrm{a}$ & $69.89 \mathrm{a}$ & 69.12 & 7.22 \\
ADF (\%) & $37.15 \mathrm{a}$ & $35.55 \mathrm{a}$ & $36.77 \mathrm{a}$ & $37.62 \mathrm{a}$ & 36.77 & 3.39 \\
LIG (\%) & $9.16 \mathrm{a}$ & $8.97 \mathrm{a}$ & $8.85 \mathrm{a}$ & $8.83 \mathrm{a}$ & 8.95 & 14.96 \\
\hline
\end{tabular}

Note. Treatments: 1 (Oat), 2 (Oat + nitrogen fertilization), 3 (Oat + Vetch), and 4 (Oat + vetch + nitrogen fertilization); DM (Dry matter); CP (Crude Protein); EE (Ethereal extract); MM (Mineral Matter); NDF (Neutral Detergent Fiber); ADF (Acid Detergent Fiber); LIG (Lignin); CV (Coeffeicient of Variation).

Averages in the same line followed by the same letter do not differ from one another $(\mathrm{P}>0.05)$ by the Tukey test.

Source: The author, 2015.

To the values of acid detergent fiber there is an oscillation among the years in which were performed the experiment having as the highest proportion in the second year when reached an average of $36.77 \%$ and when compared to the first year which average was of $26.41 \%$. However, the results from the first year were similar to the ones found from Gerdes (2005) for ADF which obtained average of $28.4 \%$ for oat consorted with species for winter crops. In Table 2 are shown the percentages related to mineral matter which content was higher for the second year (2015) with 9.24\% (MM) while in the first year was of $8.67 \%(\mathrm{MM})$.

In the second year the differences between the treatments consortium with nitrogen fertilizer compared to the treatments without fertilization were not significant between each other $(P>0.05)$. Probably it is explained by the climate conditions in the period that preceded the cut which had rainy days without luminosity and it could had influenced in the forage development. Excesses of rainfall are detrimental to the crop due to the soil saturation be able to influence in the root aeration and the excess of rain with high air humidity provokes an ambient that is not good for the plant to grow to the point that the nitrogen fertilization was not able to have an influence in the plants (Castro et al., 2012).

The contents of crude protein $(\mathrm{CP})$ in the second year did not show a difference among the treatments $(\mathrm{P}>0.05)$ maintaining a medium average of $15.16 \%(\mathrm{CP})$. While the other chemical components mineral matter, neutral detergent fiber, acid detergent fiber and lignin also not differed among each other $(\mathrm{P}>0.05)$, however these values were increased in the second year when compared to the first year showed in Table 1. The results are similar to the ones found in the experiment developed from Zacalunsy (2013), when using the same consortium of black oat + tifton 85 got an average of $15.84 \%$ of crude protein. 
It is possible to notice that occurred an increase in the dry matter content (DM), going from an average of $18.95 \%$ in the first year (Table 1) to an average of $23.99 \%$ in the second year (Table 2). There is also an increase in the percentage of mineral matter, ethereal extract and ADF and NDF in the second year. Ferolla (2005) found an average result of $15.75 \%(\mathrm{DM})$ for different planting times, result that is inferior to the ones found in this research.

To the lignin contents is verified that it did not differ significantly $(P>0.05)$ for both years $(2014$ and 2015) in the winter season. When analyzed the first year the medium average of the treatments was $7.7 \%$ whereas in the second year the medium average result was $8.95 \%$.

It is possible to identify in the Table 3 that the yield differed $(\mathrm{P}>0.05)$ among the treatments so the average is higher when compared to the one from the first year (2014) which average result was $3,136.83 \mathrm{~kg} \mathrm{ha}^{-1}$ while in the second year (2015) it was of $3.922 \mathrm{~kg} \mathrm{ha}^{-1}$.

When compared the two years of consortium fertilized (Oat + nitrogen fertilization + vetch) the yield increase was of $716.88 \mathrm{~kg} \mathrm{ha}^{-1}$. The consortium shows that even with the presence of the leguminous in the pasture, the initial application of mineral $\mathrm{N}$ in the beginning of the winter foraging seasoning increases significantly the mass production of this forage. One of the factors that may contributed to this is the fact that the nitrogen was kept in the superficial layers of the soil making it possible for the plants to absorb it by the contact ion-root and for the predominant form of locomotion of $\mathrm{N}$ is by mass flow, the axial root of the vetch did not have great advantages in the search for the nutrient (Balbinot \& Trevisan, 2012).

Table 3. Productivity of single oats, oats consortium with vetch, oats consortium with vetch and addition of nitrogen fertilization and oats with addition of nitrogen fertilization in the first year (2014) and second year (2015) of conduction of the experiment

\begin{tabular}{lllllll}
\hline Elements & Oat & Oat $+\mathbf{N}$ & Oat+ Vetch & Oat + Vetch + N & General Average & CV \\
\hline Yield 2014 $\left(\mathbf{k g ~ h a}^{-1}\right)$ & $2508.70 \mathrm{~b}$ & $3706.72 \mathrm{a}$ & $2302.84 \mathrm{~b}$ & $4029.07 \mathrm{a}$ & 3136.83 & 16.85 \\
Yield 2015 $\left(\mathbf{k g ~ h a}^{-1}\right)$ & $3276.55 \mathrm{~b}$ & $3947.33 \mathrm{ab}$ & $3718.19 \mathrm{~b}$ & $4745.95 \mathrm{a}$ & 3922 & 10.92 \\
\hline
\end{tabular}

Note. Treatments: 1 (Oat), 2 (Oat + nitrogen fertilization), 3 (Oat + Vetch), and 4 (Oat + Vetch + nitrogen fertilization); Production in $\mathrm{kg} \mathrm{ha}^{-1} ; \mathrm{CV}$ (Coeffeicient of Variation).

Averages in the same line followed by the same letter do not differ from one another $(\mathrm{P}>0.05)$.

Source: The author, 2015.

At Table 3 are presented the medium results of the three yield evaluations $\left(\mathrm{kg} \mathrm{ha}^{-1}\right)$ which had shown significant different $(\mathrm{P}>0.05)$ among the treatments being the yield in the fourth higher $4029.07 \mathrm{~kg} \mathrm{ha}^{-1}$ in the year of 2014 when compared to the treatment of oat consorted with vetch $2302.84 \mathrm{~kg} \mathrm{ha}^{-1}$ however the general average for the different treatments was $3136.83 \mathrm{~kg} \mathrm{ha}^{-1}$ in the first year, value superior than the one found from Tonial et al. (2013) which was $2637.5 \mathrm{~kg} \mathrm{ha}^{-1}$.

\section{Conclusions}

The introduction of black oat consorted with vetch and with a nitrogen fertilization in above sowing in the crop of tifton 85 during the winter period provides an increase in the yield $\mathrm{kg} \mathrm{ha}^{-1}$ and when the vetch was used it happened an increase in the contents of crude protein and dry matter in the bromatological composition of the forage.

The increase in the crude protein and dry matter content of black oats increases the efficiency of the transformation of the feed into animal weight gain due to the use of a quality bulky, where it has acceptable and sufficient levels to the nutrition of the animals of production.

\section{References}

AOAC (Association of Official Analytical Chemists). (1990). Official methods of analysis (15th ed., p. 1298). Virginia: Association of Official Analytical Chemists Inc.

Balbinot, Jr. A. A., \& Trevisan, S. (2012). Establishment and initial growth of oat cultivars for grazing. Unoesc \& Unoesc-ACET, 3(1), 23-30. Retrieved September 6, 2016, from http://editora.unoesc.edu.br/index.php/ acet/article/view/1078/pdf 
Bergoli, L. M. G., et al. (2011). Effect of cumulative animal trampling and phenation on the physical parameters of the soil in overgrazing area of cold season forage mixtures in pasture Tifton 85. XXI Brazilian Congress of Animal Science, Federal University of Alagoas, Maceió, 23 a 27 de May, 2011.

Cantarutti, R. B., Tarré, R., Macedo, R., Cadisch, G., Rezende, C. P. D., Pereira, J. M., ... Boddey, R. M. (2002). The effect of grazing intensity and the presence of a forage legume on nitrogen dynamics in Brachiaria pastures in the Atlantic Forest region of the south of Bahia, Brazil. Nutrient Cycling in Agroecosystems, 64, 257-271. https://doi.org/10.1023/A:1021415915804

Carvalho, G. G. P., \& Pires, A. J. V. (2008). Herbaceous tropical legumes in association with pasture. Archive Zootechnics, 57(R), 103-113.

Castro, G. S. A., Costa, C. H. M. D. A., \& Ferrari, N. J. (2012). Ecophysiology of White Oat. Scientia Agraria Paranaensis, 11(3), 1-15. https://doi.org/10.18188/1983-1471/sap.v11n3p1-15

Deminicis, B. B. (2009). Seed physiology for implantation by cattle in pastures (Thesis, Campos dos Goytacazes, Rio de Janeiro).

EMBRAPA. (2006). Brazilian system of soil classification (p. 306, 2nd ed.). Rio de Janeiro: EMBRAPA-SPI. Retrieved August 24, 2016, from http://www.agrolink.com.br/downloads/sistema-brasileiro-de-classificacao -dos-solos2006.pdf

Ferolla, F. S. (2005). Forage evaluation of black oatsa (Avena strigosa Schreb.) e Triticale (Xtriticosecale Wittimmack) and grazing at different planting seasons in the North of the State of Rio de Janeiro (100 f. Thesis (Master in Animal Production), Northern State University Fluminense Campos dos Goytacazes, RJ).

Ferreira, D. F. (2008). SISVAR: Program for analysis and teaching of statistics. Cientific Magazine Symposium, $6(2), 36-41$.

Gerdes, L., et al. (2005). Chemical Composition and Digestibility of Fodder Mass in Irrigated Grassland of Exclusive or Supersedes Capim-Aruana with Black Oatmeal Mixture and Azevém. Brazilian Journal of Animal Science, 34(4), 1098-1108.

IAPAR. (2013). Climate charts from Paraná. Londrina, Brazil. Retrieved August 24, 2016, from http://www.iapar.br/modules/conteudo/conteudo.php?conteudo=597

IBGE (Brazilian Institute of Geography and Statistics). (2016). Agricultural Census 2015: Preliminary Results. Rio de Janeiro: IBGE.

Lana, R. P. (2007). Nutrition and Animal Feeding: Myths and Realities (p. 128). Viçosa, MG.

Londero, A. L., Uhde, L. T., Dreilich, N. D., et al. (2013). Attributes of soil in an area with black oats intercropped with legumes overgrazed on Tifton 85 pasture submitted to animal grazing. 33rd Meeting of the Brazilian Oats Research Commission, Pelotas.

Piazzetta, R. G. (2007). Production and animal behavior in oat and ryegrass pasture, submitted to different management heights (p. 93, Dissertação mestrado, Federal University of Paraná, Curitiba). Retrieved August 24, 2016, from http://dspace.c3sl.ufpr.br/dspace/bitstream/handle/1884/10590/Disserta\%20A7\%E3 oricardo.pdf;jsessionid=DCFF288A7226D026A03DDBE6268F0ED3? sequence $=1$

Primavesi, A. C., Rodrigues, A. A., \& Godoy, R. (2000). Technical recommendations for growing oats (p. 39). São Carlos: Embrapa Animal Husbandry.

Renato, S. F., Santos, H. P., \& Roberto, S. F. (2012). Forage for Agricultural-Livestock-Forest Integration in the South-Brazilian Region. Brazilian Agricultural Research Corporation, Ministry of Agriculture, Livestock and Food Supply. Retrieved September 10, 2017, from http://www.cnpt.embrapa.br/biblio/li/li01-forrageir as/pre_texto.pdf

Silva, D. J., \& Queiroz, A. C. (2002). Food analysis (chemical and biological methods) (p. 235, 3rd ed.). Viçosa: UFV.

Tonial, R., Oliveira, P. H., Brusamarello, A. P., Dahlke, C. A., \& Baretta, D. R. (2013). Evaluation of white oat genotypes (Avena sativa L.) and black oats (Avena strigosa) of the network trial of the Brazilian Oats Research Commission (CBPA). Meeting of the Brazilian Oats Research Commission, 33, Pelotas. Annals ... Pelotas (p. 3). Retrieved July 29, 2016, from http://cgfufpel.org/aveia/trabalhos/213_2.pdf

Van Soest, P. J. (1994). Nutritional ecology of the ruminant (p. 476). Ithaca: Constock Publishing Associates. 
Van Soest, P. J., Robertson, J. B., \& Lewis, B. A. (1991). Methods for dietary fiber, neutral detergent fiber and no starch polysaccharides in relation to animal nutrition. Journal of Dairy Science, 74, 3583-3597. https://doi.org/10.3168/jds.S0022-0302(91)78551-2

Vilela, H. (2005). Pasture: Selection of Forage Plants Implantation and fertilization (p. 98). Viçosa, MG.

Zacalusny, W. (2013). Evaluation of dry mass production and protein concentration of wintering forage in tifton 85 (33 f., Completion of Course Work, Pontifical Catholic University of Paraná, Toledo).

\section{Copyrights}

Copyright for this article is retained by the author(s), with first publication rights granted to the journal.

This is an open-access article distributed under the terms and conditions of the Creative Commons Attribution license (http://creativecommons.org/licenses/by/4.0/). 